\title{
Does smoke-free legislation and smoking outside bars increase feelings of stigmatization among smokers? Findings from the International Tobacco Control (ITC) Netherlands Survey
}

Citation for published version (APA):

Nagelhout, G. E., Willemsen, M. C., Gebhardt, W. A., van den Putte, B., Hitchman, S. C., Crone, M. R., Fong, G. T., van der Heiden, S., \& de Vries, H. (2012). Does smoke-free legislation and smoking outside bars increase feelings of stigmatization among smokers? Findings from the International Tobacco Control (ITC) Netherlands Survey. Health \& Place, 18(6), 1436-1440.

https://doi.org/10.1016/j.healthplace.2012.08.001

Document status and date:

Published: 01/11/2012

DOI:

10.1016/j.healthplace.2012.08.001

Document Version:

Publisher's PDF, also known as Version of record

Document license:

Taverne

Please check the document version of this publication:

- A submitted manuscript is the version of the article upon submission and before peer-review. There can be important differences between the submitted version and the official published version of record. People interested in the research are advised to contact the author for the final version of the publication, or visit the DOI to the publisher's website.

- The final author version and the galley proof are versions of the publication after peer review.

- The final published version features the final layout of the paper including the volume, issue and page numbers.

Link to publication

\footnotetext{
General rights rights.

- You may freely distribute the URL identifying the publication in the public portal. please follow below link for the End User Agreement:

www.umlib.nl/taverne-license

Take down policy

If you believe that this document breaches copyright please contact us at:

repository@maastrichtuniversity.nl

providing details and we will investigate your claim.
}

Copyright and moral rights for the publications made accessible in the public portal are retained by the authors and/or other copyright owners and it is a condition of accessing publications that users recognise and abide by the legal requirements associated with these

- Users may download and print one copy of any publication from the public portal for the purpose of private study or research.

- You may not further distribute the material or use it for any profit-making activity or commercial gain

If the publication is distributed under the terms of Article 25fa of the Dutch Copyright Act, indicated by the "Taverne" license above,

Download date: 26 Apr. 2023 
Short Report

\title{
Does smoke-free legislation and smoking outside bars increase feelings of stigmatization among smokers? Findings from the International Tobacco Control (ITC) Netherlands Survey
}

\author{
Gera E. Nagelhout ${ }^{\mathrm{a}, \mathrm{b}, *}$, Marc C. Willemsen ${ }^{\mathrm{a}, \mathrm{b}}$, Winifred A. Gebhardt ${ }^{\mathrm{c}}$, Bas van den Putte ${ }^{\mathrm{d}}$, \\ Sara C. Hitchman ${ }^{\mathrm{e}}$, Matty R. Crone ${ }^{\mathrm{f}}$, Geoffrey T. Fong ${ }^{\mathrm{e}, \mathrm{g}}$, Sander van der Heiden ${ }^{\mathrm{c}}$, Hein de Vries ${ }^{\mathrm{a}}$ \\ a Maastricht University (CAPHRI), Maastricht, The Netherlands \\ b STIVORO Dutch Expert Centre on Tobacco Control, The Hague, The Netherlands \\ ${ }^{\mathrm{c}}$ Leiden University, Leiden, The Netherlands \\ d University of Amsterdam, Amsterdam, The Netherlands \\ e University of Waterloo, Waterloo, Ontario, Canada \\ ${ }^{\mathrm{f}}$ Leiden University Medical Center, Leiden, The Netherlands \\ ${ }^{g}$ Ontario Institute for Cancer Research, Toronto, Ontario, Canada
}

\section{A R T I C L E I N F O}

\section{Article history:}

Received 23 February 2012

Received in revised form

18 July 2012

Accepted 3 August 2012

Available online 14 August 2012

\section{Keywords:}

Stigmatization

Public policy

Smoking

The Netherlands

\begin{abstract}
A B S T R A C T
This study examined whether smokers' perceived level of stigmatization changed after the implementation of smoke-free hospitality industry legislation and whether smokers who smoked outside bars reported more perceived stigmatization. Longitudinal data from the International Tobacco Control (ITC) Netherlands Survey was used, involving a nationally representative sample of 1447 smokers aged 15 years and older. Whether smoke-free legislation increases smokers' perceived stigmatization depends on how smokers feel about smoking outside. The level of perceived stigmatization did not change after the implementation of smoke-free hospitality industry legislation in the Netherlands, possibly because most Dutch smokers do not feel negatively judged when smoking outside.
\end{abstract}

(c) 2012 Elsevier Ltd. All rights reserved.

\section{Introduction}

Smoke-free legislation protects non-smokers from tobacco smoke pollution (also known as second-hand smoke) in public places. Smoke-free legislation also indirectly communicates that smoking is not socially acceptable and may therefore contribute to the denormalization of smoking (Hammond et al., 2006, Ritchie et al., 2010a). Consequently, a possible unintended consequence of smoke-free legislation is that continuing smokers may experience increased feelings of stigmatization. They may feel that not only is their cigarette smoke banned from public places, but that they are themselves banned and may thus think that others perceive smokers negatively.

Stigmatization occurs 'when elements of labeling, stereotyping, separating, status loss, and discrimination co-occur in a power situation that allows these processes to unfold' (Link and

\footnotetext{
* Corresponding author. STIVORO Dutch Expert Centre on Tobacco Control, PO Box 16070, 2500 BB The Hague, The Netherlands.

Tel.: +31 7031204 23; fax: +31703120495.

E-mail addresses: gnagelhout@stivoro.nl,

gera.nagelhout@maastrichtuniversity.nl (G.E. Nagelhout).
}

Phelan, 2001, p. 382). Because smoke-free legislation physically separates smokers from non-smokers by requiring smokers to smoke outside, it has been suggested that smoke-free legislation may increase feelings of stigmatization (Gottlieb et al., 1992). Several qualitative studies found that smoke-free legislation in workplaces and public places is associated with feelings of stigmatization (Gottlieb et al., 1992; Hargreaves et al., 2010; Poland, 1998; Ritchie et al., 2010a, 2010b and Thompson et al., 2007). In these studies, smokers report that they feel 'like a leper' (Ritchie et al., 2010b), 'an outcast' (Thompson et al., 2007), or 'ashamed' (Baha and Le Faou, 2010) when they have to go outside to smoke. To our knowledge, only one quantitative study examined the association between exposure to smoke-free legislation and stigmatization and this study found no association among smokers in New York City (Stuber et al., 2008).

In the current study, we used longitudinal data from two survey waves of the International Tobacco Control (ITC) Netherlands Survey. Smoke-free hospitality industry legislation was implemented in the Netherlands between these two survey waves, in July 2008. The Netherlands had a smoking prevalence of $27 \%$ both before and after the implementation of the legislation (Nagelhout et al., 2011a), with a smoking prevalence of $29 \%$ 
among low educated people and 20\% among high educated people (Nagelhout et al., 2012). The Netherlands has moderately strong tobacco control policies compared to other European countries (Joossens and Raw, 2011). The implementation of smoke-free legislation was not comprehensive (smoking rooms were allowed) and there were high levels of non-compliance among bars (Nagelhout et al., 2011b). As a consequence, levels of support for smoke-free bars among smokers were low compared to other European countries with more comprehensive laws and did not increase much after the implementation (Mons et al., 2012a). Also, voluntary home smoking bans were relatively uncommon among Dutch smokers compared to other European countries (Mons et al., 2012b).

We examined whether smokers' level of perceived stigmatization changed after the implementation of smoke-free hospitality industry legislation, and whether smokers who smoked outside bars had stronger perceptions of stigmatization. Also, we examined associations between perceived stigmatization with feelings of shame, being judged, and being proud when smoking outside hospitality establishments after the smoke-free legislation. Finally, differences between smokers with low, moderate, and high education were investigated, because persons with lower socioeconomic status may be more vulnerable to the negative effects of stigmatization (Major and O'Brien, 2005).

\section{Methods}

\subsection{Sample}

Dutch smokers aged 15 years and older were recruited from a probability-based web database (Nagelhout et al., 2010). Potential respondents were identified as smokers (having smoked at least 100 cigarettes in their lifetime and currently smoking at least once per month) by means of a short screening survey in March 2008. In April 2008, 2331 smokers were invited to participate in a web survey. Of these smokers, 1820 participated in the first survey (78.1\%). In April and May 2009 all 1820 smokers of the baseline survey were recontacted for the followup survey and 1447 took part (79.5\%).

\subsection{Measurements}

Control variables were gender, age group, and heaviness of smoking in the 2008 survey. Age was categorized as 15-24, 2539, 40-54, and 55 years and older. The Heaviness of Smoking Index (HSI) was created as the sum of two categorical measures: cigarettes per day and time before smoking the first cigarette of the day (Heatherton et al., 1989). HSI values ranged from 0 to 6 and are positively associated with nicotine dependence. Education was measured in the 2008 survey and categorized in three levels: low, moderate, and high.

Smoking outside bars was measured in the 2009 survey by asking continuing smokers who reported visiting a bar since the implementation of the smoke-free hospitality industry legislation in July 2008, whether they had smoked outside the bar at their last visit. Smokers who did not visit bars after the implementation of smoke-free hospitality industry legislation were categorized as not having smoked outside bars. We also controlled for bar visiting.

Feelings when smoking outside were measured in the 2009 survey by asking respondents how they feel when they are smoking outside the hospitality industry. Three statements were used: "You are ashamed if others see you smoking", "You think that passers-by judge you negatively", and "You are proud of yourself for still smoking, in spite of everything". Respondents could answer on a five-point Likert scale whether they agreed or disagreed with these statements.

Perceived stigmatization of smokers was measured in both survey waves by asking respondents how they thought most Dutch people perceive smokers nowadays (Stuber et al., 2008; Goldstein, 1991). Respondents were asked to indicate on sevenpoint Likert bipolar scales whether they thought most people perceive smokers as nice versus not nice, strong versus weak, free versus not free, pathetic versus not pathetic, and persevering versus not persevering (only the endpoints of the scales were given). A factor analysis showed that these items loaded on one factor, with factor loadings between 0.39 and 0.82 . A mean score of these items (Cronbach's $\alpha=0.72$ ) was used as a measure of perceived stigmatization that ranged from 1 (nice, strong, free, not pathetic, and persevering) to 7 (not nice, weak, not free, pathetic, and not persevering).

\subsection{Ethics}

The ITC Netherlands surveys were cleared for ethics by the Research Ethics Board of the University of Waterloo and the Central Committee on Research Involving Human Subjects in the Netherlands.

\subsection{Analyses}

All analyses were performed with SPSS version 17.0 and were weighted by age and gender to be representative of the smoker population in the Netherlands. More details on the weighting procedure can be found elsewhere (ITC Project, 2009). Differences between respondents with low, moderate, and high educational levels were tested with $\chi^{2}$ tests and ANOVA F-tests.

Multivariate linear mixed model analysis was performed to assess whether the level of perceived stigmatization changed between before (2008) and after (2009) the implementation of smoke-free hospitality industry legislation. This technique extends multivariate linear regression to longitudinal analyses of repeated measures. The two individual perceived stigmatization scale scores were taken as the dependent variable and the survey wave was designated as the repeated measure variable, while controlling for gender, age group, educational level, and heaviness of smoking. Interactions of educational level with survey wave were added to the model to examine whether the change in perceived stigmatization between 2008 and 2009 was the same for respondents from all educational levels.

Multivariate linear regression analysis was performed to determine whether smoking outside bars and feelings when smoking outside hospitality establishments predicted a change in perceived stigmatization between 2008 and 2009. The dependent variable was the stigmatization scale in 2009. The independent variables were gender, age group, educational level, heaviness of smoking, visited bars, smoking outside bars, feels ashamed when smoking outside, feels negatively judged when smoking outside, feels proud when smoking outside, and stigmatization in 2008. Interactions of educational level with smoking outside bars and with feelings when smoking outside were added to the regression analysis to examine whether there were educational differences in the possible effect of smoking outside bars and feelings when smoking outside on perceived stigmatization.

\section{Results}

Characteristics of respondents are shown in Table 1 . Most respondents (69.6\%) had visited bars since the implementation of 
Table 1

Characteristics of study respondents ( $n=1447)$.

\begin{tabular}{lc}
\hline & $\%$ \\
& \\
\hline 2008 Survey & \\
Gender & \\
Female (\%) & 46.2 \\
Male (\%) & 53.8 \\
Age group & \\
15-24 years (\%) & 12.3 \\
25-39 years (\%) & 27.7 \\
40-54 years (\%) & 35.0 \\
55 years and older (\%) & 25.0 \\
Educational level & \\
Low (\%) & 40.0 \\
Moderate (\%) & 41.7 \\
High (\%) & 18.3 \\
Heaviness of smoking & \\
Mean & \\
Standard deviation & 2.4 \\
2009 Survey & 1.5 \\
Visited bars & \\
Yes (\%) & \\
No (\%) & \\
Smoking outside bars & \\
Yes (\%) & \\
No (\%) & \\
Feels ashamed when smoking & outside \\
Agree (\%) & 6.4 \\
Disagree (\%) & 75.5 \\
Neutral (\%) & 18.1 \\
Feels negatively judged when smoking outside \\
Agree (\%) \\
Disagree (\%) \\
Neutral (\%) \\
Feels proud when smoking outside \\
Agree (\%) \\
Disagree (\%) \\
Neutral (\%) \\
\hline
\end{tabular}

a Low dependence (0)-high dependence (6).

the smoke-free hospitality industry legislation. About half of the smokers (46.5\%) had smoked outside the bar at their last visit, while the other half either did not visit bars (30.4\%), did not smoke at the bar (12.4\%), or smoked inside the bar (10.8\%). Few smokers felt ashamed when smoking outside hospitality establishments (6.4\%), one in five smokers felt negatively judged (20.1\%), and one in 10 felt proud (10.4\%). High educated smokers visited bars more often $\left(\chi^{2}=44.91, p<0.001\right)$ and smoked more often outside the $\operatorname{bar}\left(\chi^{2}=10.64, p=0.005\right)$ than lower educated smokers. Lower educated smokers felt proud more often when smoking outside $\left(\chi^{2}=24.65, p<0.001\right)$ than higher educated smokers.

The mean score of respondents on the perceived stigmatization scale was four on a scale from one to seven both before and after the implementation of smoke-free hospitality industry legislation (Table 2). This means that respondents thought that most other people perceive smokers as neutral. Low, moderate, and high educated smokers did not differ significantly in their perception of stigmatization $(F=0.48, p=0.619)$. Respondents thought that most other people perceive smokers as weak $(M=5.12, \mathrm{SD}=1.49)$ and not persevering $(M=5.16, \mathrm{SD}=1.52)$, while they thought that most other people perceive smokers as neutral on the 'nice-not nice' $(M=3.70$, $\mathrm{SD}=1.46)$, 'free-not free' $(M=4.21, \mathrm{SD}=1.55)$, and 'pathetic-not pathetic' $(M=4.15, \mathrm{SD}=1.88)$ continuums.

A multivariate linear mixed model analysis (not shown in the table) showed that the level of perceived stigmatization did not change significantly after the implementation of smoke-free hospitality industry legislation ( $\beta$ of survey wave $=-0.02$,
Table 2

Mean scores on perceived stigma scale in 2008 and 2009 by smoking outside and feelings when smoking outside ( $n=1447)$.

\begin{tabular}{lll}
\hline & $\begin{array}{l}\text { Perceived stigma in } 2008 \text { mean } \\
\text { (standard deviation) }\end{array}$ & $\begin{array}{l}\text { Perceived stigma in 2009 mean } \\
\text { (standard deviation) }\end{array}$ \\
\hline \multicolumn{2}{c}{ All respondents } \\
4.46 (1.09) & $4.41(1.10)$ \\
Smoking outside bars & \\
Yes $\quad 4.51(1.11)$ & $4.49(1.02)$ \\
No $\quad 4.40(1.07)$ & $4.34(1.17)$ \\
Feels ashamed when smoking outside & \\
Agree $\quad 4.78(1.08)$ & $4.89(0.90)$ \\
Disagree & $4.41(1.09)$ & $4.37(1.11)$ \\
Neutral & $4.53(1.09)$ & $4.44(1.07)$ \\
Feels negatively judged when smoking outside \\
Agree & $4.84(1.00)$ & $4.89(0.99)$ \\
Disagree & $4.26(1.10)$ & $4.19(1.09)$ \\
Neutral & $4.47(1.08)$ & $4.39(1.09)$ \\
Feels proud when smoking outside & \\
Agree & $3.97(1.26)$ & $3.82(1.39)$ \\
Disagree & $4.64(1.01)$ & $4.67(0.98)$ \\
Neutral & $4.40(1.09)$ & $4.30(1.07)$ \\
\hline
\end{tabular}

${ }^{\text {a }}$ Low perceived stigma (1)-high perceived stigma (7).

$p=0.437)$. Educational level had no significant association with a change in perceived stigmatization.

Table 2 shows that perceived stigmatization was approximately the same for respondents who did and did not smoke outside bars, while perceived stigmatization was relatively high for smokers who felt ashamed or negatively judged when smoking outside hospitality establishments. Also, perceived stigmatization was relatively low for smokers who felt proud when smoking outside. A multivariate linear regression analysis (Table 3) confirmed that smoking outside bars in 2009 was not associated with perceived stigmatization $(\beta=0.02, p=0.613)$. However, feelings of being negatively judged when smoking outside were associated with an increase in perceived stigmatization $(\beta=0.11, p<0.001)$, while feelings of being proud when smoking outside were associated with a decrease in perceived stigmatization $(\beta=-0.08, p=0.001)$. There were no significant interactions of smoking outside bars or feelings when smoking outside with the educational level (not shown in the table).

\section{Discussion}

In our study, increased feelings of stigmatization were found only among smokers who felt negatively judged by passers-by when smoking outside hospitality establishments. However, in the Netherlands, most smokers did not feel negatively judged when smoking outside. This explains why we found that the overall level of perceived stigmatization did not change after the implementation of smoke-free hospitality industry legislation and that smoking outside bars did not increase feelings of stigmatization.

Earlier research (Stuber et al., 2008) found that lower educated smokers perceive lower levels of stigmatization than higher educated smokers. In the current study, we did not find significant differences in perceived stigmatization between educational levels. There are, however, concerns that lower educated smokers internalize the stigmatized identity more than higher educated smokers (Farrimond and Joffe, 2006). This means that lower educated smokers may not only think that most other people perceive smokers as weak and not persevering, but they may also come to see themselves as weak and not persevering because they 
Table 3

Multivariate linear regression analysis predicting perceived stigmatization in 2009 $(n=1264)$

\begin{tabular}{|c|c|}
\hline & $\beta(95 \% \mathrm{CI})$ \\
\hline \multicolumn{2}{|l|}{ Gender } \\
\hline Female & $0.00(-0.05$ to 0.05$)$ \\
\hline Male & 0.00 \\
\hline \multicolumn{2}{|l|}{ Age group } \\
\hline $15-24$ years & $0.04(-0.02$ to 0.13$)$ \\
\hline 25-39 years & $0.08(0.02-0.15)^{* *}$ \\
\hline $40-54$ years & $0.08(0.02-0.14)^{* * *}$ \\
\hline 55 years and older & 0.00 \\
\hline \multicolumn{2}{|l|}{ Educational level } \\
\hline Low & $-0.07(-0.14 \text { to } 0.00)^{*}$ \\
\hline Moderate & $-0.03(-0.10$ to 0.03$)$ \\
\hline High & 0.00 \\
\hline Heaviness of smoking & $-0.03(-0.08$ to 0.02$)$ \\
\hline \multicolumn{2}{|l|}{ Visited bars } \\
\hline Yes & $0.02(-0.04$ to 0.08$)$ \\
\hline No & 0.00 \\
\hline \multicolumn{2}{|l|}{ Smoking outside bars } \\
\hline Yes & $0.02(-0.05$ to 0.08$)$ \\
\hline No & 0.00 \\
\hline \multicolumn{2}{|c|}{ Feels ashamed when smoking outside } \\
\hline Agree & $0.02(-0.03$ to 0.08$)$ \\
\hline Disagree & $0.05(-0.01$ to 0.11$)$ \\
\hline Neutral & 0.00 \\
\hline \multicolumn{2}{|c|}{ Feels negatively judged when smoking outside } \\
\hline Agree & $0.11(0.06-0.17)^{* * * * *}$ \\
\hline Disagree & $-0.07(-0.13 \text { to }-0.02)^{*}$ \\
\hline Neutral & 0.00 \\
\hline \multicolumn{2}{|c|}{ Feels proud when smoking outside } \\
\hline Agree & $-0.08(-0.14 \text { to }-0.03)^{* * *}$ \\
\hline Disagree & $0.08(0.03-0.14)^{* *}$ \\
\hline Neutral & 0.00 \\
\hline Stigmatization in 2008 & $0.42(0.39-0.49)^{* * * *}$ \\
\hline
\end{tabular}

smoke. This may contribute to continued smoking despite high levels of perceived stigmatization (Farrimond and Joffe, 2006).

Our results suggest that smoke-free hospitality industry legislation may increase stigmatization in countries where smokers feel negatively judged when smoking outside. In other words, this may occur in countries where smoking is more denormalised than in the Netherlands. Our study focused on smoking outside hospitality establishments after the implementation of smokefree hospitality industry legislation, and the findings may not generalize to effects of smoking outside workplaces. Also, specific characteristics of the Dutch legislation may have influenced the results.

A limitation of our study was that our measure of perceived stigmatization may not capture the entire experience of smoker related stigmatization. Although other studies have also measured perceived stigmatization by asking respondents how they thought most others perceive smokers (Goldstein, 1991; Stuber et al., 2008), a study on HIV related stigma showed that this is only one dimension of perceived stigmatization and that stigmatization also includes personalized stigma, disclosure concerns, and a negative self-image (Berger et al., 2001).

As argued by others (Ritchie et al., 2010b), we believe that policymakers should continue implementing smoke-free legislation despite possible unintended consequences such as stigmatization. However, policymakers also have the moral responsibility to support individuals who experience negative consequences of smoke-free legislation (Bayer, 2008), for example by providing free cessation counseling and medication to smokers who want to quit smoking. When these individuals are supported, the known benefits of smoke-free legislation for non-smokers and smokers who want to quit smoking will by far outweigh the possible unintended consequences for continuing smokers.

\section{Funding}

This work was supported by The Netherlands Organisation for Health Research and Development (ZonMw). Geoffrey Fong was supported by a Senior Investigator Award from the Ontario Institute for Cancer Research and a Prevention Scientist Award from the Canadian Cancer Society Research Institute.

\section{Acknowledgments}

We thank Lorraine Craig, Ruth Loewen, Mary Thompson, Christian Boudreau, and other members of the ITC Project and of the Propel Centre for Population Health Impact (University of Waterloo) for assistance with project management, survey development, and data cleaning. We thank Mariëtte Haak for her contributions to this study as part of her Masters' thesis and for commenting on an earlier version of this paper.

\section{References}

Baha, M., Le Faou, A.L., 2010. Smokers' reasons for quitting in an anti-smoking social context. Public Health 124, 225-231.

Bayer, R., 2008. Stigma and the ethics of public health: not can we but should we. Social Science and Medicine 67, 463-472.

Berger, B.E., Ferrans, C.E., Lashley, F.R., 2001. Measuring stigma in people with HIV: psychometric assessment of the HIV stigma scale. Research in Nursing and Health 24, 518-529.

Farrimond, H.R., Joffe, H., 2006. Pollution, peril and poverty: a British study of the stigmatization of smokers. Journal of Community and Applied Social Psychology 16, 481-491.

Goldstein, J., 1991. The stigmatization of smokers: an empirical investigation. Journal of Drug Education 21, 167-182.

Gottlieb, N.H., Lovato, C.Y., Weinstein, R., Green, L.W., Eriksen, M.P., 1992. The implementation of a restrictive worksite smoking policy in a large decentralized organization. Health Education and Behavior 19, 77-100.

Hammond, D., Fong, G.T., Zanna, M.P., Thrasher, J.F., Borland, R., 2006. Tobacco denormalization and industry beliefs among smokers from four countries. American Journal of Preventive Medicine 31, 225-232.

Hargreaves, K., Amos, A., Highet, G., Martin, C., Platt, S., Ritchie, D., White, M. 2010. The social context of change in tobacco consumption following the introduction of 'smokefree' England legislation: a qualitative, longitudinal study. Social Science and Medicine 71, 459-466.

Heatherton, T.F., Kozlowski, L.T., Frecker, R.C., Rickert, W., Robinson, J., 1989. Measuring the heaviness of smoking: using self-reported time to the first cigarette of the day and number of cigarettes smoked per day. British Journal of Addiction 84, 791-800.

ITC Project, 2009. ITC Netherlands Survey Waves 1-3 (2008-2009). Technical Report. University of Waterloo, Waterloo, Ontario, Canada, Available from: < www.itcproject.org $>$.

Joossens, L., Raw, M., 2011. The tobacco control scale 2010 in Europe. Paper presented at the Fifth European Conference on Tobacco or Health, Amsterdam, The Netherlands.

Link, B.G., Phelan, J.C., 2001. Conceptualizing stigma. Annual Review of Sociology 27, 363-385.

Major, B., O'Brien, L.T., 2005. The social psychology of stigma. Annual Review of Psychology 56, 393-421.

Mons, U., Nagelhout, G.E., Guignard, R., McNeill, A., Van den Putte, B., Willemsen, M.C., Brenner, H., Pötschke-Langer, M., Breitling, L.P., 2012a. Comprehensive smoke-free policies attract more support from smokers in Europe than partial policies. European Journal of Public Health 22 (Suppl. 1), 10-16.

Mons, U., Nagelhout, G.E., Allwright, S., Guignard, R., Van den Putte, B., Willemsen, M.C., Fong, G.T., Brenner, H., Pötschke-Langer, M., Breitling, L.P., 2012b. Impact of national smoke-free legislation on home smoking bans: findings from the International Tobacco Control (ITC) Policy Evaluation Project Europe Surveys. Tobacco Control. Published online first: 13 February 2012.

Nagelhout, G.E., Willemsen, M.C., De Vries, H., 2011a. The population impact of smoke-free workplace and hospitality industry legislation on smoking behaviour. Findings from a National Population Survey. Addiction 106, 816-823. 
Nagelhout, G.E., Mons, U., Allwright, S., Guignard, R., Beck, F., Fong, G.T., De Vries, H. Willemsen, M.C., 2011b. Prevalence and predictors of smoking in "smokefree" bars. Findings from the International Tobacco Control (ITC) Europe Surveys. Social Science and Medicine 72, 1643-1651.

Nagelhout, G., Willemsen, M., Thompson, M., Fong, G., Van den Putte, B., De Vries, H., 2010. Is web interviewing a good alternative to telephone interviewing? Findings from the International Tobacco Control (ITC) Netherlands Survey. BMC Public Health 10, 351.

Nagelhout, G.E., De Korte-de Boer, D., Kunst, A.E., Van der Meer, R.M., De Vries, H. Van Gelder, B.M., Willemsen, M.C., 2012. Trends in socioeconomic inequalities in smoking prevalence, consumption, initiation, and cessation between 2001 and 2008 in The Netherlands. Findings from a national population survey. BMC Public Health 12, 303.
Poland, B.D., 1998. Smoking, stigma, and the purification of public space. In: Kearns, R.A., Gesler, W.M. (Eds.), Putting Health Into Place: Landscape, Identity, and Well-Being. Syracuse University Press, New York.

Ritchie, D, Amos, A, Martin, C., 2010a. Public places after smoke-free-a qualitative exploration of the changes in smoking behaviour. Health and Place 16 461-469.

Ritchie, D., Amos, A., Martin, C., 2010b. But it just has that sort of feel about it a leper-stigma, smoke-free legislation and public health. Nicotine and Tobacco Research 12, 622-629.

Stuber, J., Galea, S., Link, B.G., 2008. Smoking and the emergence of a stigmatised social status. Social Science and Medicine 67, 420-430.

Thompson, L., Pearce, J., Barnett, J.R., 2007. Moralising geographies: stigma, smoking islands and responsible subjects. Area 39, 508-517. 